\title{
Sexual abuse in irritable bowel syndrome: To ask or not to ask - That is the question
}

\author{
Alexandra Ilnyckyj MD, Charles N Bernstein MD
}

\section{A Ilnyckyj, CN Bernstein. Sexual abuse in irritable bowel syndrome: To ask or not to ask - That is the question. Can J G astroenterol 2002;16(11):801-805}

B A C K G R O U N D : I rritable bowel syndrome (IBS) is a common and costly disorder in Canada. The paucity of medical treatment underscores the importance of examining every element of the management approach. Data exist supporting an increased prevalence of abuse among individuals with IBS. Importantly, the pathophysiology underlying the link between abuse and IBS is increasingly understood. Treatment recommendations by opinion leaders support an abuse inquiry. However, many clinicians view abuse inquiry as an ethical dilemma.

MET H OD: C anadian gastroenterologists were surveyed to determine current practice patterns and to identify barriers to inquiry. Barriers cited by clinicians were explored within an ethical context.

RESU LT S: A buse inquiry is not universally practised in $C$ anada. Fifty-four per cent of the membership of $C$ anadian A ssociation of $G$ astroenterologists responded to the survey. They reported inquiring into abuse histories in approximately $50 \%$ of patients with IBS. The frequency of inquiry declined when male patients were considered. The primal barriers cited were time constraints (25\%), personal comfort with abuse issues (25\%) and lack of resources for addressing the abuse (33\%). I mportantly, only a minority (10\%), cited abuse history as irrel evant to the management of the patient. IN T ER PRETAT ION : Physicians identify significant barriers to pursuing an inquiry into abuse. H owever, a minority cited 'clinical irrelevance' as a primal barrier, the implicit statement being that the abuse history has clinical relevance. This view is consistent with opinion leaders and published treatment recommendations. Therefore, by not inquiring into the abuse history, physicians are not fulfilling their ethical responsibility to the patient. Physicians need to resolve their barriers to inquiry. Furthermore, they need to familiarize themselves with treatment recommendations and include this review in their consultation.

Key Words: Gastroenterologist; I rritable bowel syndrome; Sexual abuse; Survey

\section{$L$ a violence sexuelle en cas de syndrome du côlon irritable : D emander ou ne pas demander, telle est la question}

HIST ORIQUE : Le syndrome du côlon irritable $(\mathrm{SCI})$ est un trouble courant et coûteux au $\mathrm{C}$ anada. Le peu de traitements médicaux étaye l'importance d'évaluer chaque élément de la démarche de prise en charge. Des données soutiennent une prévalence plus élevée de violence sexuelle chez les personnes atteintes du SCI. II convient de souligner qu'on comprend de mieux en mieux la physiopathologie sous-tendant le lien entre la violence sexuelle et le $\mathrm{SCl}$. Les recommandations en matière de traitement données par des leaders d'opinion appuient la nécessité de s'informer des possibilités de violence sexuelle. Cependant, de nombreux cliniciens considèrent ce type de questions comme un dilemme moral.

MÉT H O D OLO GIE : U ne enquête a été menée auprès de gastro-entérologues canadiens pour établir les modèles de pratique actuels et pour repésuite à la page suivante

Section of $\mathrm{G}$ astroenterology, D epartment of Internal M edicine, U niversity of $M$ anitoba, W innipeg, $M$ anitoba

Correspondence and reprints: Dr A lexandra IInyckyj, Section of $\mathrm{G}$ astroenterology, 409 Tache A venue, St B oniface G eneral H ospital, W innipeg,

M anitoba R2H 2A 6. Telephone 204-237-2796, fax 204-233-7154, e-mail ailnycky@sbgh. mb.ca

Received for publication J une 13, 2002. A ccepted 0 ctober 16, 2002 
rer les obstacles aux questions sur la violence sexuelle. Les obstacles cités par les cliniciens ont été examinés dans un contexte éthique.

RÉ SU LTAT S : Les questions sur la violence sexuelle ne sont pas posées partout au Canada. Cinquante-quatre pour cent des membres de I'A ssociation canadienne de gastroentérologie ont répondu au sondage. Ils ont indiqué s'informer des antécédents de violence sexuelle chez environ $50 \%$ des patients atteints du SCl. La fréquence des questions diminuait lorsque le patient était de sexe masculin. Les principaux obstacles cités étaient le manque de temps (25\%), un malaise personnel face à la violence sexuelle ( $25 \%$ ) et un manque de ressources pour réagir à ce type de violence ( $33 \%$ ). II faut souligner que seule une minorité ( $10 \%$ ) a cité les antécédents de violence sexuelle comme non pertinents à la prise en charge du patient.

rritable bowel syndrome (IBS) is a colossal health care problem in the western world. In Canada, in 1997, the direct costs alone of managing this disorder represented $0.5 \%$ of our national health expenditure (1). Pharmacological therapy is limited (2). Despite the much anticipated introduction of the new drug classes binding to the various 5-hydroxytryptamine receptors, these agents have brought disappointment. O ne agent was withdrawn from the $C$ anadian market, while another has demonstrated limited benefit. Psychological interventions have demonstrated efficacy (3) but are neither widely nor universally available. Since IBS is a considerable personal and societal burden, it is imperative to consider every element of the contemporary management strategy. A current working strategy includes exploring psychosocial stressors and their possible relationship to the onset of IBS $(4,5)$.

The reported prevalence of rates of abuse are highly variable ( $6 \%$ to $62 \%$ ) depending on the era, selected population, definition of abuse and method of inquiry (6). A mong patients with IBS, the incidence of sexual abuse has been documented as $22 \%$ in a community sample (7) and as high as $44 \%$ in referral centres (8). A history of abuse has been shown to contribute independently to the health status of any individual presenting with gastrointestinal symptoms (9). Specifically, this study demonstrated that patients with functional gastrointestinal disorders had more severe abuse experiences than patients with organic gastrointestinal conditions.

A Ithough no specific pathogenetic link has been developed that directly ties significant life stressors such as sexual abuse with visceral sensation or visceral motor responses, progress has been made in showing altered cortical responses in IBS compared with other gastrointestinal conditions in response to noxious visceral stimuli $(10,11)$. A nimal models of noxious rectal stimulation in infancy have been developed, which demonstrate changes in cortical and subcortical activation of the brain (12). It is speculated that altered central pain processing may contribute to the propensity for the disturbed motor and sensory gastrointestinal dysfunction that characterizes some subsets of patients with IBS.

Human studies have explored pain thresholds, coping strategies and psychiatric diagnoses in patients with func-
IN T ER PRÉTAT ION : Les médecins ont repéré d'importants obstacles face aux questions relatives à la violence sexuelle. Cependant, une minorité a cité la «non-pertinence clinique » comme principal obstacle, l'énoncé implicite voulant que les antécédents de violence sexuelle aient une pertinence clinique. $C$ e point de vue est en harmonie avec les recommandations des leaders d'opinion et de traitements publiées. Par conséquent, lorsqu'ils ne posent pas de questions au sujet des antécédents de violence sexuelle, les médecins faillissent à leur responsabilité éthique envers le patient. Les médecins doivent régler les obstacles reliés aux questions sur la violence sexuelle. De plus, ils doivent se familiariser avec les recommandations en matière de traitement, qu'ils doivent inclure dans leur consultation.

tional disorders and abuse histories. Those who reported abuse had lowered pain thresholds, more maladaptive coping strategies and a higher incidence of psychiatric disorders than those who did not report abuse (13).

The high incidence of abuse among patients with IBS, coupled with the animal and human data, has led opinion leaders to promote abuse inquiry as essential to medical history taking (14). Treatment guidelines have been developed and promoted to assist in conducting an inquiry, specifically in patients presenting with severe symptoms (6). No data exist to support that either disclosure or discussion of abuse leads to measurable outcome benefits. Furthermore, there are no data pertaining to patients' impressions of being queried by a consultant.

W hile an understanding of the relationship between abuse and IBS must evolve, it is an ethical dilemma at present as to whether physicians should be compelled to inquire into the abuse history of IBS patients. If physicians choose not to ask, are they fulfilling their ethical responsibility to the patient? If physicians are not asking, then it is critical to understand why not. To ask or not to ask - that is the question.

\section{METHODS}

Physician practise patterns with regard to abuse inquiry were explored in the fall of 2001, by surveying the membership of the Canadian A ssociation of Gastroenterology ( $C A G$ ). $M$ embers were requested to complete a mailed survey aimed at capturing practice patterns and potential limitations to inquiry. Five potential limitations were hypothesized a priori and presented in the survey. Respondents were asked to rank the factors they felt limited their inquiry (Figure 1). Only physician members of the CA G were included in the survey if they were in active clinical practice and residents of $C$ anada.

\section{RESU LT S}

Of the 509 eligible clinicians, 271 (53\%) replied and formed the sample. Demographics revealed the following characteristics: gender - $86 \%$ male; practice type - 44\% community full-time practice $/ 37.5 \%$ academic full-time practice/18.5\% academic part-time; 147 (54\%) graduated from medical school in 1980 or earlier. There was no association between physician sex or era of graduation with 


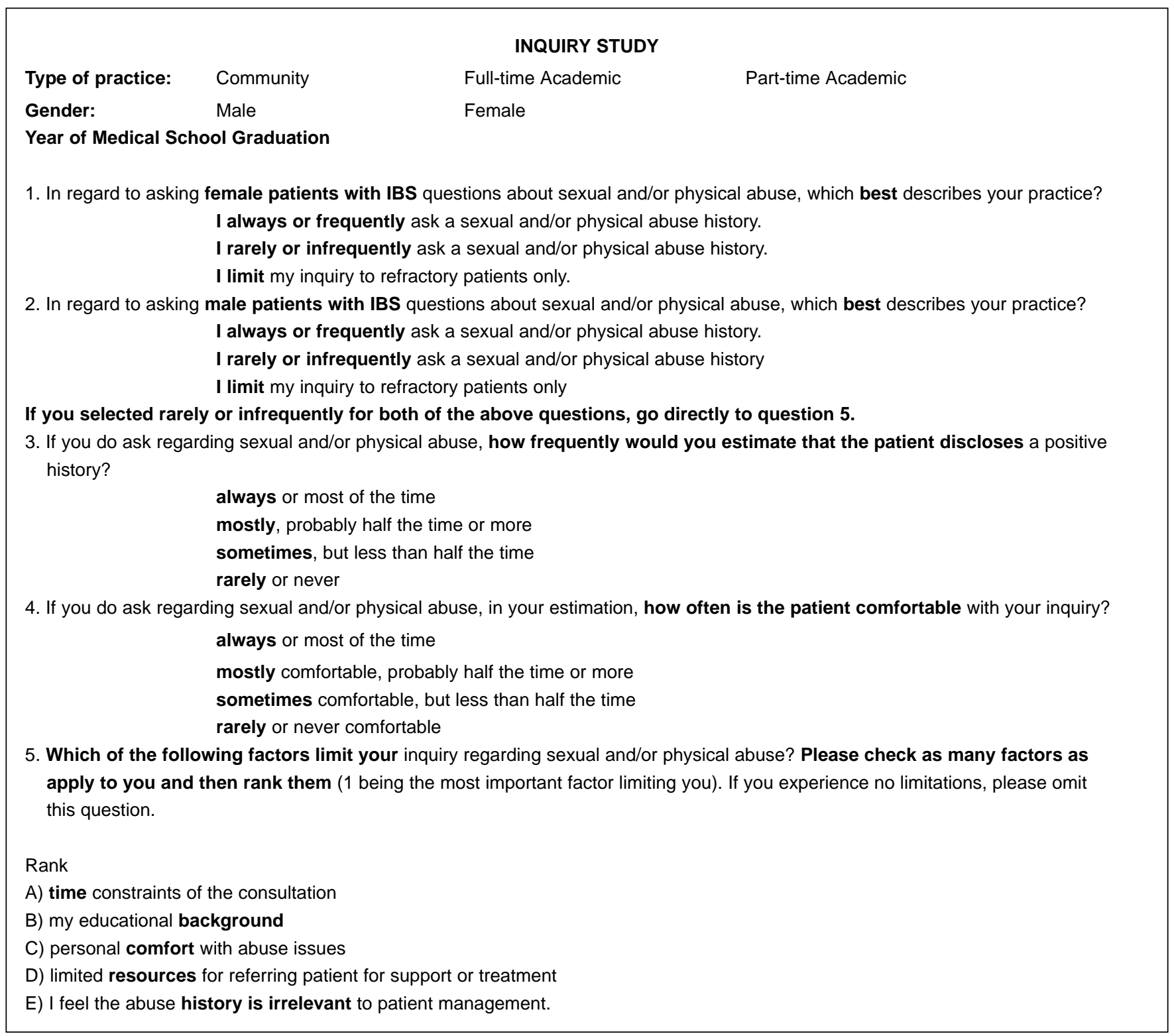

Figure 1) Survey designed to capture practice patterns and potential limitations to inquiry regarding possible sexual or physical abuse

respect to inquiry.

The survey demonstrated that the $C$ anadian gastroenterologist inquires into the abuse history of female IBS patients in only about $50 \%$ cases. A pproximately one third confine their inquiry to patients with refractory IBS. A buse inquiry in male IBS patients is less frequent (Table 1). Despite inquiry, $75 \%$ reported infrequently gaining disclosure from patients regarding abuse, and $46 \%$ estimated that patients were rarely or less than half the time comfortable with the inquiry.

Seventy-one per cent stated that they had limitations to inquiry; the most commonly cited factors were resources, personal comfort and time constraints as opposed to educational background or a view that abuse history is irrelevant to management (Table 2). Overall, inquiry into abuse history in IBS patients is not universally practised in Canada.

\section{IN TERPRETATION}

The response to the survey of $54 \%$ was acceptable. In 1997, the CA G membership was surveyed regarding their use of cyclosporine in ulcerative colitis. O nly $34 \%$ chose to voice their view on this clinical practice (15).

A $n$ implicit assumption of our survey was that a sexual abuse inquiry was of value in assessing patients with IBS. We acknowledge that the benefits of the disclosure and discussion of abuse have not been fully studied. It might be argued that an inquiry into sexual abuse is not of value but this argument was not supported in our survey; only $10 \%$ of respondents ranked the view that the abuse history is irrelevant to patient management as their primary barrier to inquiry.

There are no data exploring whether patients with IBS are harmed by inquiry into abuse history. Patients' preferences regarding inquiry of victimization experiences were explored by surveying a general group of community 
TABLE 1

\section{Percentage of physicians reporting inquiring into} abuse history

\begin{tabular}{lcc}
\hline & Female patients (\%) & Male patients (\%) \\
\hline Always/frequently & 23 & 11 \\
Rarely/infrequently & 47 & 61 \\
Limited to refractory & 30 & 28 \\
\hline
\end{tabular}

TABLE 2

Breakdown by percentage of the single most limiting factor to inquiry

\begin{tabular}{lc}
\hline & Percentage \\
\hline Personal educational background & 6 \\
View abuse as irrelevant & \\
$\quad$ to managment & 10 \\
Time constraints of the consultation & 25 \\
Personal comfort with abuse issues & 25 \\
Limited resources for referring & \\
$\quad$ patients for treatment & 33 \\
\hline
\end{tabular}

patients and primary care providers (16). This survey documented that most patients favoured a routine inquiry into physical or sexual abuse and overwhel mingly felt the physician could be of assistance to them. One third of the primary care givers believed inquiry should be routine; however, a minority incorporated this into their practice. The incidence of sexual abuse in the sample was $16 \%$. It should be underscored that in this survey the physician was a primary care provider.

Time constraints of the consultations were cited by $25 \%$ of gastroenterologists as their most important barrier to inquiry. This may relate to the brevity of the consultant relationship with the patient. Consultation consists of a brief patient-physician interaction. It is both time and frequency limited; consultation usually consists of one meeting. The treatment guidelines acknowledge the importance of establishing a good relationship with the patient before proceeding to an abuse inquiry. A rguably, this may be difficult to attain within the context of a consultation.

With the constraints of current clinical practice, this may underscore the potential value of having nurse clinicians assist in the management and care of patients with IBS. N urse clinicians or physician assistants can spend more time with a patient. This may promote a stronger relationship, thus facilitating inquiry into abuse. A dditionally, the consultant has the option of delegating the inquiry to the referring physician. The consultant can use his or her report as a tool to educate the primary care physician regarding the relationship between abuse and IBS.

Since an inquiry into sexual abuse or handling of disclosure may lengthen consultation time, physicians might consider time constraints as a barrier to inquiry. This position is difficult to defend. A ssessment must al ways be thorough. A physician is expected to inquire into the smoking history of a patient with cough. Disclosure of smoking requires engag- ing in education regarding cessation. This undoubtedly adds to the length of the consultation. Consultants must adapt their use of time to meet the needs of the consultation versus adapting the assessment to meet an arbitrary time allocation.

A nother $25 \%$ of gastroenterologists cited personal comfort with abuse issues as the primal barrier to inquiry. Certainly one expects physicians to define their personal boundaries and limitations. A the same time, "the health of my patient will be my first consideration" (Hippocratic $\mathrm{O}$ ath). Physicians must address their personal discomfort and resolve it. A buse in Canadian society is common; physicians cannot be excused of involvement due to personal discomfort.

The most commonly cited barrier (33\%) was lack of resources for treatment referral; if we can't treat it, we should ignore it. Patients have the right to understand causal or contributing factors to their disorders irrespective of treatment options. There are many examples in modern medicine where resources for treatment are lacking. Every gastroenterologist is aware of the substantial numbers of $\mathrm{C}$ anadians who die yearly awaiting liver transplantation. However, physicians expend tremendous resources preparing and educating patients for a treatment option unlikely to come to fruition. Furthermore, in the case of abuse, patients may be encouraged by the link to their illness to help themselves or to seek help outside the health sector.

IBS is a common and costly disorder. It has long been recognized that there is an association between functional disorders and abuse. Increasingly, mechanisms for this link are being proposed. The majority of gastroenterologists are not incorporating an abuse inquiry into their history taking but the barriers they cite are not defensible. Therefore, by not inquiring into abuse, physicians are not fulfilling their ethical obligations.

\section{CONCLUSIONS}

Gastroenterologists need to resolve their barriers to abuse inquiry. We need to familiarize ourselves with published treatment recommendations regarding abuse inquiry and systemically include this in our repertoire of history taking in patients with IBS. A sk! That is the answer.

A C KN OWLEDGEMEN TS: Dr George Webster, Clinical Ethicist, St Boniface H ospital, $U$ niversity of $\mathrm{M}$ anitoba is acknowledged for his contribution in reviewing the manuscript.

\section{REFEREN CES}

1. Bentkover JD, Field C, G reene EM, Plourde V, C asciano JP. The economic burden of irritable bowel syndrome in $\mathrm{C}$ anada. $\mathrm{C}$ an J Gastroenterol 1999;13(Suppl A ):89A -98A.

2. Jaiwala J, Imperiale TF, Kroenke K. Pharmacologic treatment of the irritable bowel syndrome; a systematic review of randomized, controlled trials. A nn Intern M ed 2000;133:136-47.

3. Blanchard EB, M alamood HS. Psychological treatment of irritable bowel syndrome. Prof Psych Res Pract 1996;27:241-4.

4. Drossman DA, Thompson GW. The irritable bowel syndrome: 
Review and a graduated multicomponent treatment approach. A nn Intern M ed 1992;116:1009-16.

5. D rossman DA . Diagnosing and treating patients with refractory functional gastrointestinal disorders. A nn Intern M ed 1995;123:688-97.

6. Drossman DA, Talley N J, Leserman J, O Iden KW, Barrierio M A Sexual and physical abuse and gastrointestinal illness. Review and recommendations. A nn Intern M ed 1995;123:782-94.

7. Talley N J, Fett SL, Zinsmeister A F. Self reported abuse and gastrointestinal disease in outpatients: A ssociation with irritable bowel type symptoms. A m J G astroenterol 1995:90:366-71.

8. Drossman DA, Leserman J, Nachman $\mathrm{G}$, et al. Sexual and physical abuse in women with functional or organic gastrointestinal disorders. A nn Intern M ed 1990;113:828-33.

9. Drossman DA , Zhiming L, Leserman I, Toomey TC. H ealth status by gastrointestinal diagnosis and abuse history. $\mathrm{G}$ astroenterology 1996;110:999-1007.

10. M ertz H, M organ V, Tanner $G$, et al. Regional cerebral activation in irritable bowel syndrome and control subjects with painful and nonpainful rectal distension. G astroenterology 2000;118:842-8.
11. Bernstein CN, Frankenstein UN, Rawsthorne P, Pitz M, Summers $\mathrm{R}, \mathrm{M}$ clntyre MC. Cortical mapping of visceral pain in patients with gastrointestinal disorders using functional magnetic resonance imaging. A m J Gastroenterol 2002. (In Press)

12. Shaoyong $Y$, Long JM, N ass PH, Ingram DK, D rowell DM . CN S processing of noxious colorectal distention: A murine model using immediate early gene transcription of c-Fos. G astroenterology 2000;118:A 4419.

13. Scarcini IC, M CD onald-H aile J, Bradley LA, Richter JE. A Itered pain perception and psychosocial features among women with gastrointestinal disorders and history of abuse: A preliminary model. A m J Med 1994;97:108-18.

14. Drossman DA, Leserman J. Sexual and physical abuse history and medical practice. G en H osp Psychiatry 1995;17:71-4.

15. A tkinson $K A, M C D$ onald JW, Lamba B, Feagan BG. Intravenous Cyclosporine for severe attacks of ulcerative colitis: A survey of C anadian gastroenterolgist. C an J G astroenterol 1997;7:583-7.

16. Friedman LS, Samet JH, Roberts M S, M udlin M, H ans P. Inquiry about victimization experiences. A rch Intern M ed 1992;152:1186-90. 


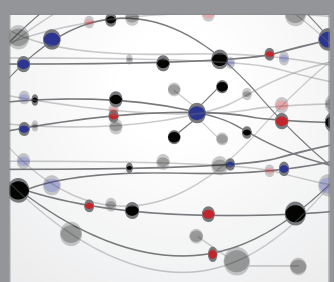

The Scientific World Journal
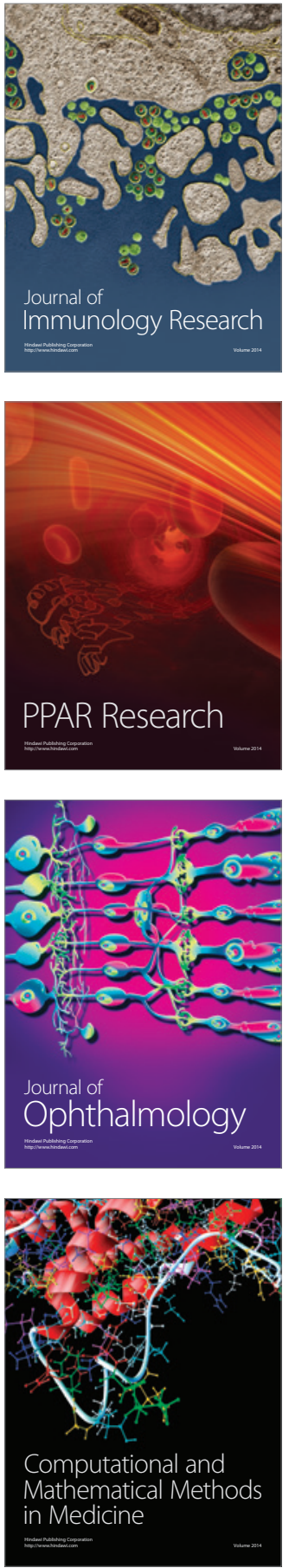

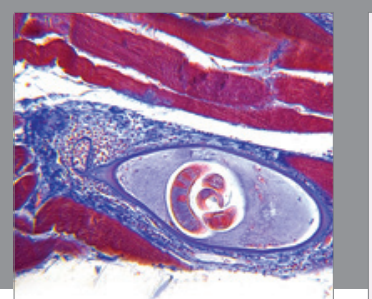

Gastroenterology Research and Practice

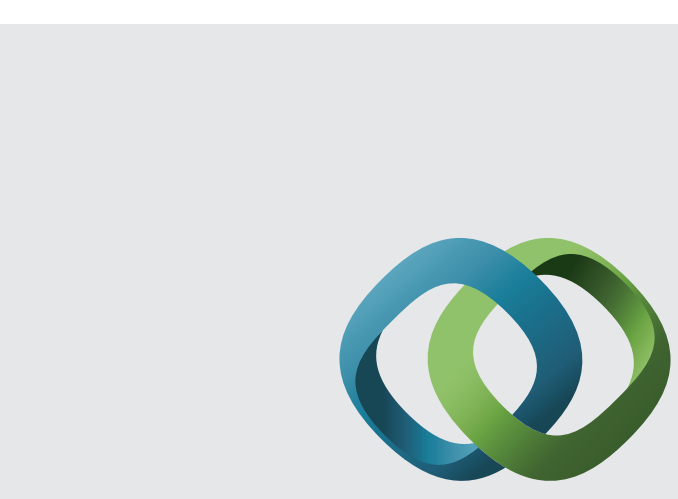

\section{Hindawi}

Submit your manuscripts at

http://www.hindawi.com
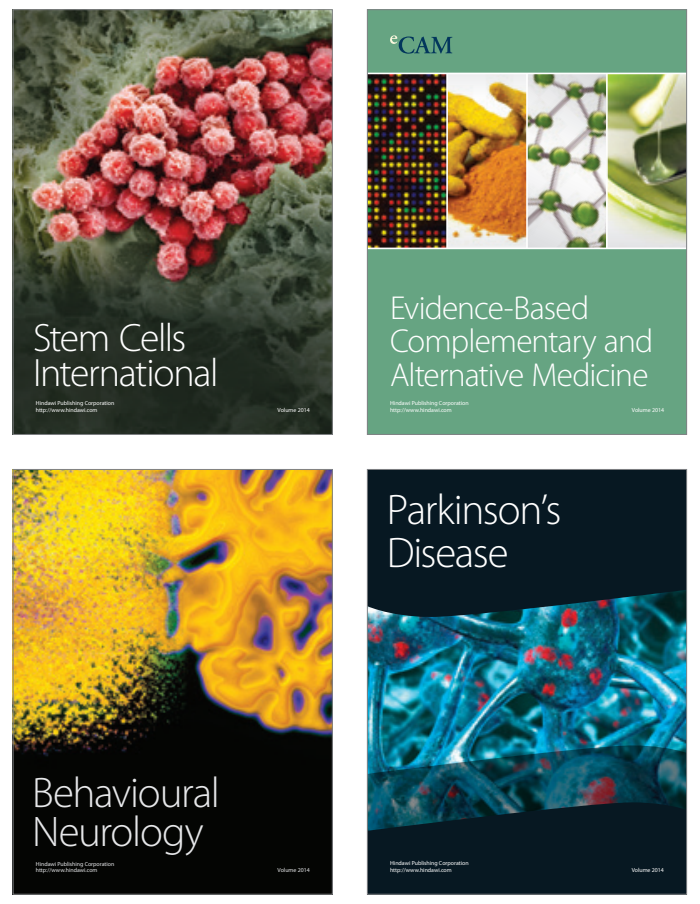
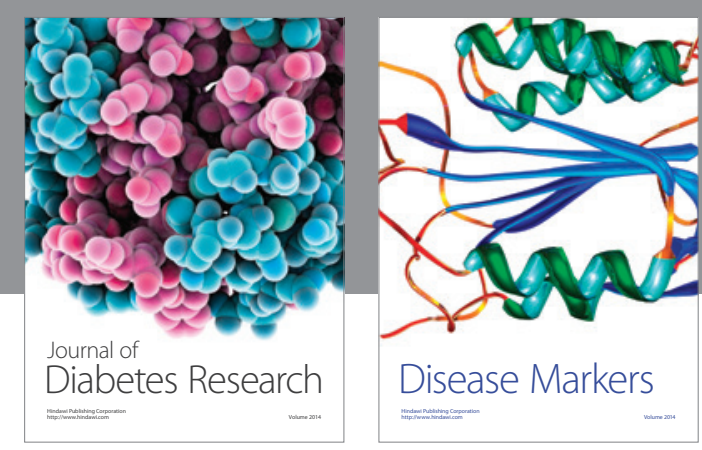

Disease Markers
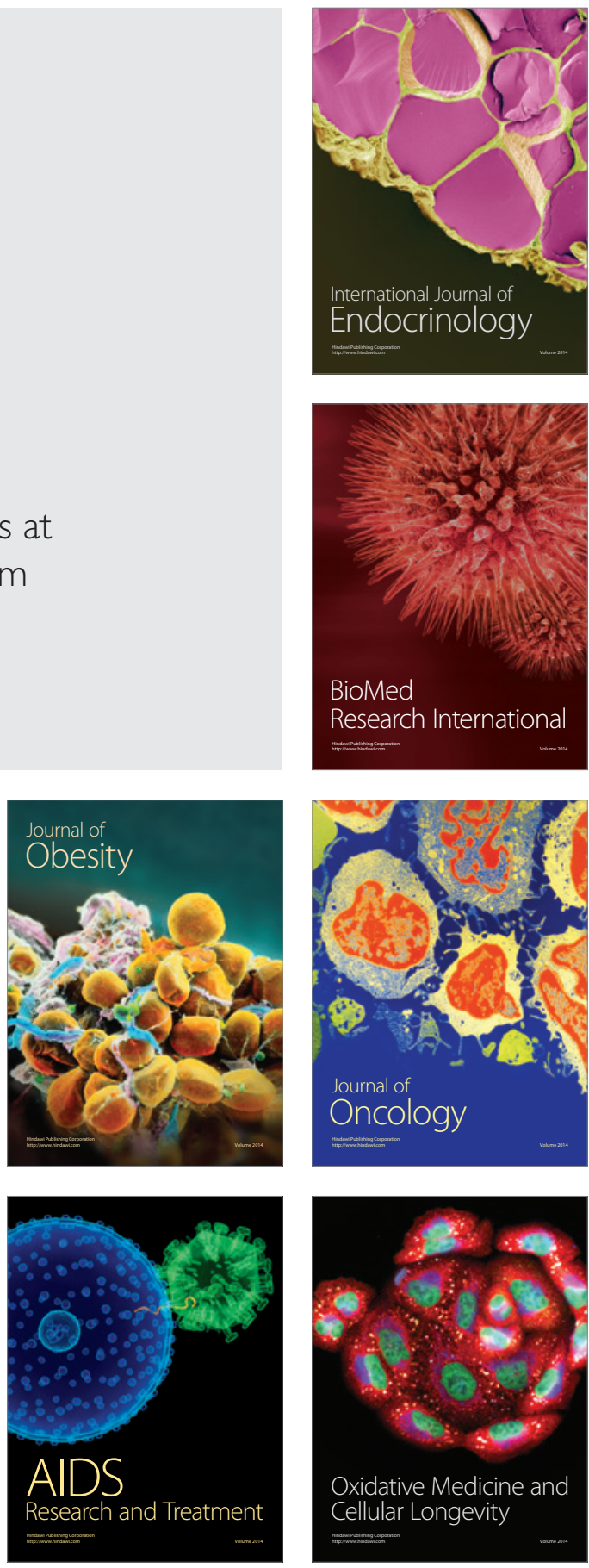